\title{
PENDUGAAN STATUS TROPIK RAWA BANJIRAN DESA SEDANG KECAMATAN SUAK TAPEH KABUPATEN BANYUASIN DENGAN PENDEKATAN KELIMPAHAN FITOPLANKTON
}

\author{
Indah Anggraini Yusanti \\ Program Studi IImu Perikanan, Fakultas Perikanan Universitas PGRI, \\ Palembang, Indonesia \\ E-mail : indahayusanti@gmail.com
}

Received February 2019 , Accepted April 2019

\begin{abstract}
ABSTRAK
Penelitian tentang pendugaan status tropik Rawa Banjiran Desa Sedang Kecamatan Suak Tapeh Kabupaten Banyuasin dengan pendekatan kelimpahan fitoplankton telah dilakukan pada bulan Juli 2017. Metode yang digunakan adalah metode survei, sedangkan pengambilan sampel fitoplankton dilakukan pada 3 (tiga) stasiun yaitu stasiun Rawa Nebong Kuning, Rawa Poron dan Rawa Banan dengan menggunakan metode purposive random sampling. Hasil penelitian menunjukkan bahwa ratarata kelimpahan fitoplankton pada stasiun 1 Rawa Nebong Kuning sebesar 39 ind/L yang mengindikasikan perairan Rawa Nebong Kuning memiliki tingkat kesuburan yang rendah dan termasuk perairan oligotrofik, rata-rata kelimpahan fitoplankton di stasiun 2 Rawa Poron sebesar 15,42 ind/L yang mengindikasikan perairan Rawa Poron memiliki tingkat kesuburan yang rendah dan termasuk perairan oligotrofik, sedangkan rata-rata kelimpahan fitoplankton di stasiun 3 Rawa Banan sebesar 23,08 ind/L yang mengindikasikan perairan Rawa Banjiran memiliki tingkat kesuburan yang rendah dan termasuk perairan oligotrofik.
\end{abstract}

Kata kunci : Fitoplankton, Rawa Banjiran, Status Tropik

\section{ABSTRACT}

ESTIMATION OF TROPHIC STATUS SWAMP FLOOD WATERS IN SEDANG VILLAGE, SUBDISTRICT SUAK TAPEH, DISTRICT BANYUASIN WITH APPROACH ABUNDANCE OF PHYTOPLANKTON.

Research on the estimation of trophic status of swamp floods of Sedang village, Subdistrict Suak Tapeh, District Banyuasin with the approach of phytoplankton abundance has been done in July 2017. Survey method was used in this research while phytoplankton sampling was done at 3 (three) stations, they were Nebong Kuning swamp, Poron swamp and Banan swamp by using purposive random sampling method. The results showed that the abundance of phytoplankton at station 1 of Nebong Kuning swamp was 39 ind/L indicating that Nebong Kuning swamp waters 
had low fertility rate and was clustered as oligotrophic, the abundance of phytoplankton at station 2 of Poron swamp was 15,42 ind/L which indicates Poron swamp waters had a low fertility rate and was clustered as oligotrophic, while the abundance of phytoplankton at station 3 Banan swamp was 23,08 ind/L which indicates the Banan swamp had low fertility rate and was clustered as oligotrophic.

Keywords : Phytoplankton, Swamp Flood, Trophic Status

\section{PENDAHULUAN}

Rawa Banjiran merupakan kawasan lahan rendah yang senantiasa memiliki kepekaan tergenang air baik dalam kurun waktu tertentu maupun sepanjang tahun (Kordi, 2008). Salah satu Rawa Banjiran yang ada adalah Rawa Banjiran yang terletak di Desa Sedang Kecamatan Suak Tapeh Kabupaten Banyuasin, Sumatera Selatan. Oleh masyarakat setempat, Rawa Banjiran merupakan daerah penting karena merupakan areal penangkapan sumberdaya perikanan, pemukiman penduduk hingga perkebunan. Dengan adanya peningkatan aktifitas, cepat atau lambat akan memberikan dampak terhadap keberlangsungan sumberdaya alam, khususnya sumberdaya perairan di Rawa Banjiran Desa Sedang Kecamatan Suak Tapeh Kabupaten Banyuasin Provinsi Sumatera Selatan.

Pemantauan kondisi tingkat kesuburan (status tropik) perairan perlu dilakukan agar diperoleh data awal kondisi perairan Rawa Banjiran Desa Sedang Kecamatan Suak Tapeh Kabupaten Banyuasin Provinsi Sumatera Selatan.

Penentuan tingkat kesuburan perairan (status tropik) dapat dilihat dari parameter kelimpahan fitoplankton (Efrizal, 2006). Fitoplankton merupakan parameter biologi yang dapat dijadikan indikator untuk mengevaluasi kualitas tingkat kesuburan suatu perairan (Yuliana, 2012 dalam Yusanti, 2017). Menurut Nugroho (2006) dalam Maresi (2015), fitoplankton dijadikan indikator kualitas dan tingkat kesuburan perairan karena siklus hidupnya pendek, respon yang sangat cepat terhadap perubahan lingkungan. Selain itu juga, Efrizal (2006) menambahkan bahwa fitoplakton memegang peranan penting sebagai sumber makanan bagi organisme perairan karena kemampuannya untuk berfotosintesis. Melati (2005) dalam Iswanto (2015) menambahkan fitoplankton adalah penyumbang oksigen terbesar di dalam perairan karena fitoplankton adalah pengikat awal energi matahari.

Tujuan dilakukannya penelitian ini adalah untuk mengetahui tingkat kesuburan (status tropik) perairan Rawa Banjiran berdasarkan kelimpahan fitoplankton di Desa Sedang Kecamatan Suak Tapeh Kabupaten Banyuasin Sumatera Selatan. 


\section{MATERI DAN METODE}

\section{Waktu dan Tempat}

Penelitian ini dilaksanakan pada bulan Juli 2017 di Rawa Banjiran Desa Sedang Kecamatan Suak Tapeh Kabupaten Banyuasin Provinsi Sumatera Selatan. Identifikasi Fitoplankton dilakukan di Balai Riset Perikanan Perairan Umum Palembang.

\section{Pengambilan Sampel Fitoplankton}

Pengambilan sampel fitoplankton dilakukan secara purposive random sampling pada 3 (tiga) stasiun yaitu :

- Stasiun 1 Rawa Nebong Kuning, memiliki kedalaman 2,5m - 4m. Merupakan daerah aktifitas penduduk.

- Stasiun 2 Rawa Poron, memiliki kedalaman 2,3m - 3m. Merupakan daerah yang tidak terdapat banyak aktifitas penduduk.

- Stasiun 3 Rawa Banan, memiliki kedalaman 2,3m - 3,8m. Merupakan daerah yang tidak terdapat banyak aktifitas penduduk.

Sampel air diambil menggunakan ember berukuran $5 \mathrm{~L}$ sebanyak 20 kali ulangan. Kemudian air sampel disaring menggunakan plankton net berukuran 25 mesh yang pada ujungnya terdapat botol pengumpul.

Kemudian air yang terdapat pada botol pengumpul di pindahkan kedalam botol sampel sebanyak $20 \mathrm{ml}$. Sampel air kemudian diawetkan dengan formalin $4 \%$ sebanyak 5 tetes, beri keterangan pada labelnya kemudian dilakukan identifikasi.

\section{Identifikasi Sampel Fitoplakton}

Identifikasi sampel fitoplankton dilakukan di Balai Riset Perikanan Perairan Umum Palembang dengan menggunakan mikroskop dan Sedgwick rafter. Pengamatan jenis fitoplankton mengacu pada buku identifikasi Mizuno (1979).

\section{Parameter Pengamatan}

\section{(a) Kelimpahan Fitoplankton}

Kelimpahan fitoplankton diperoleh dengan melakukan perhitungan jumlah individu tiap liter sampel air. (APHA, 2005 dalam Indrayani, 2014)

Keterangan :

$$
N=\frac{n s x v a}{v s x v c}
$$

$\mathrm{N}=$ jumlah plankton per liter air contoh

ns = jumlah plankton pada sedgewick-rafter counting cell

va = volume air terkonsentrasi dalam botol contoh (cc)

vs = volume air dalam preparat sedgewick-rafter counting cell

vc = volume air contoh yang disaring 


\section{(b) Penentuan Status Trofik}

Penentuan status trofik berdasarkan kelimpahan fitoplankton mengacu pada Lander (1978) dalam Suryanto (2009), yaitu :

a) Perairan Oligotrofik merupakan perairan yang memiliki tingkat kesuburan rendah dengan kelimpahan fitoplankton berkisar antara $0-2000 \mathrm{ind} / \mathrm{L}$.

b) Perairan Mesotrofik merupakan perairan yang memiliki tingkat kesuburan sedang dengan kelimpahan fitoplankton berkisar antara $2000-15.000$ ind/L.

c) Perairan Eutrofik merupakan perairan yang memiliki tingkat kesuburan sedang dengan kelimpahan fitoplankton berkisar antara $>15.000 \mathrm{ind} / \mathrm{L}$.

\section{Analisis Data}

Analisis data pada penelitian ini dilakukan secara deskriptif dengan cara mengumpulkan, menyusun, menganalisa dan menafsirkan data dan disajikan dalam bentuk tabel.

\section{HASIL DAN PEMBAHASAN}

\section{Hasil}

Jenis fitoplankton yang teridentifikasi pada Rawa Banjiran Desa Sedang Kecamatan Suak Tapeh Kabupaten Banyuasin Provinsi Sumatera Selatan terdiri dari 3 (tiga) kelas, yaitu Bacillariophyceae, Cyanophyceae, dan Chlorophyceae. Pada kelas Bacillariophyceae ditemukan 13 genus, kelas Chlorophyceae ditemukan 6 genus dan Cyanophyceae ditemukan 2 genus. Sedangkan rata-rata kelimpahan fitoplankton pada stasiun 1 Rawa Nebong kuning menunjukkan nilai rata-rata kelimpahan fitoplankton tertinggi dibandingkan stasiun lainnya yaitu sebesar 39 ind/L sedangkan nilai rata-rata kelimpahan fitoplankton terendah terdapat pada stasiun 2 Rawa Poron yaitu sebesar 15,42 ind/L.

\section{Pembahasan}

Berdasarkan hasil identifikasi diperoleh 3 (tiga) kelas fitoplankton, yaitu Bacillariophyceae, Cyanophyceae, dan Chlorophyceae. Pada kelas Bacillariophyceae ditemukan 13 genus, yaitu Coscinodiscus, Diatoma, Navicula, Synedra, Fragilaria, Stephanodiscus, Tabellaria, Pinularia, Cyclotella, Coconeis, Nitszchia, Thalassiora, Hyalodiscus, pada kelas Chlorophyceae ditemukan 6 genus, yaitu Closterium, Cosmarium, Mougeotia, Selenastrum, Spirogyra, Ulothrix dan pada kelas Cyanophyceae ditemukan 2 genus, yaitu Oscillatoria dan Anabaena. Selengkapnya disajikan pada Tabel 1. 
Kelimpahan fitoplankton didefinisikan sebagai jumlah individu plankton per satuan volume air dan dapat pula dinyatakan dalam jumlah sel per liter air (Raymont, 1984 dalam Iswanto, 2015).

Tabel 1. Kelimpahan fitoplankton di Rawa Banjiran Desa Sedang Kecamatan Suak Tapeh Kabupaten Banyuasin Provinsi Sumatera Selatan

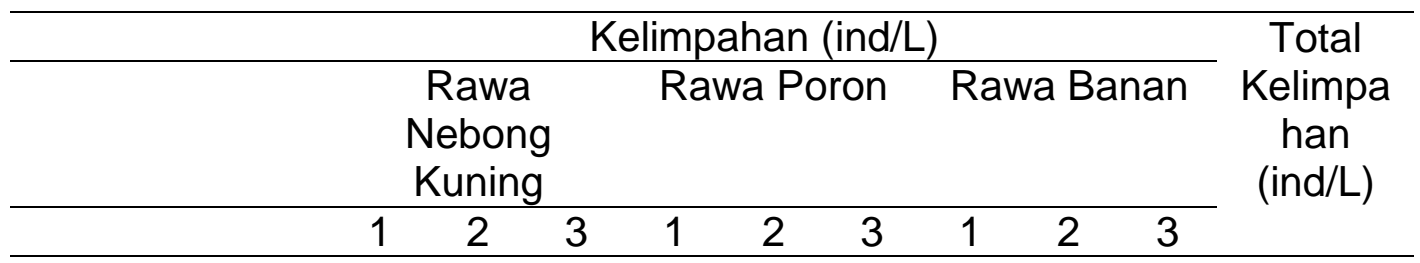

Bacillariophyceae

$\begin{array}{lcccccccccc}\text { Coscinodiscus } & - & 0,2 & - & - & - & 6,2 & 1,2 & 0,7 & 0,5 & 9 \\ \text { Diatoma } & - & 0,7 & - & 1 & 0,2 & 1,2 & 0,2 & 1 & - & 4,5 \\ \text { Navicula } & 0.5 & 1 & 0,7 & 6,2 & 0,5 & 2 & 0,2 & 1,2 & 1,5 & 14 \\ \text { Synedra } & - & 0,5 & - & - & 0 & - & 2 & - & - & 2,5 \\ \text { Fragilaria } & 1,7 & 1 & 0,2 & 1,5 & 1 & 0,2 & - & 1 & 1,2 & 8 \\ \text { Stepanodiscus } & 0,7 & 1,5 & 0,5 & - & 0,5 & 1 & 9,7 & 2 & - & 16 \\ \text { Tabellaria } & 1,2 & - & - & - & - & - & - & - & - & 1,25 \\ \text { Pinularia } & 0,2 & - & - & - & 0,5 & - & - & - & 0,7 & 1,5 \\ \text { Cyclotella } & 0,2 & 1 & 0,7 & - & 1,2 & - & 5,5 & - & 0,2 & 9 \\ \text { Coconeis } & - & 0,2 & - & - & - & - & - & - & 0,2 & 0,5 \\ \text { Nitszchia } & - & - & - & 0,7 & - & 0,2 & - & - & - & 1 \\ \text { Thalassiora } & - & - & - & - & - & 2 & - & - & - & 2 \\ \text { Hyalodiscus } & 0,5 & - & - & - & - & 1,2 & - & - & - & 1,75 \\ \text { Cyanophyceae } & & & & & & & & & & \\ \text { Oscillatoria } & 18, & 7,2 & 63, & 10, & - & 5 & 12 & - & 12, & 129,05 \\ \text { Anabaena } & 8 & & 2 & 2 & & & & & 5 & \\ & 1,2 & 1,5 & - & 1 & 0,5 & - & 10, & - & 0,7 & 15,5\end{array}$

Chlorophyceae

\begin{tabular}{lcccccccccc} 
Closterium & 0,7 & 1,2 & - & - & - & 0,5 & 1,2 & - & - & 3,75 \\
Cosmarium & - & 1 & 0,2 & - & - & - & - & 0,7 & 2 & 4 \\
Mougeotia & - & - & 4 & - & - & - & - & - & - & 4 \\
Selenastrum & - & 2,5 & - & - & - & - & - & - & - & 2,5 \\
Spirogyra & 1,5 & - & - & - & - & - & - & - & - & 1,5 \\
Ulothrix & - & - & - & - & - & 1,2 & - & - & - & 1,25 \\
\multicolumn{1}{c}{ Total } & 27, & 19, & 69, & $20,4,5$ & 21 & 42, & 6,7 & 19, & 232,55 \\
& 5 & 75 & 75 & 75 & & 75 & 5 & 75 & \\
\hline Rata-rata & 39 & \multicolumn{10}{c}{15,42} & \multicolumn{7}{c}{23,08} & 77,50 \\
\hline
\end{tabular}


Tabel 1 diatas menunjukkan nilai rata-rata kelimpahan fitoplankton pada stasiun 1 Rawa Nebong kuning sebesar 39 ind/L, stasiun 2 Rawa Poron sebesar 15,42 ind/L, stasiun 3 Rawa Banan sebesar 23,08 ind/L.

Tingginya nilai rata-rata kelimpahan fitoplankton pada stasiun 1 Rawa Nebong kuning diduga karena fitoplankton mampu beradaptasi dengan kondisi lingkungan. Hal ini dapat di lihat dengan ditemukannya kelas Cyanophyceae yang memiliki kelimpahan tertinggi dibandingkan dengan kelas lainnya di setiap stasiun pengamatan. Cyanophyceae merupakan fitoplankton yang termasuk dalam alga biru. Richmond (2005) dalam Suryanto (2009) menyatakan bahwa fitoplankton jenis Cyanophyceae mampu beradaptasi dengan keadaan yang tidak menguntungkan.

Selain itu, tingginya kelimpahan fitoplankton diduga karena adanya faktor unsur hara dan intensitas cahaya matahari. Dugaan ini selaras dengan pendapat Nontji (2006) dalam Iswanto (2015) yang menyatakan bahwa fitoplankton mengandung klorofil yang mampu berfotosintesis dengan menyerap energi matahari untuk mengubah bahan inorganik menjadi bahan organik.

Hutabarat dan Evan (1986) dalam Iswanto (2015) menambahkan bahwa, fitoplankton dalam melakukan kegiatan fotosintesis membutuhkan cahaya matahari. Penyinaran cahaya matahari akan berkurang secara cepat dengan semakin tingginya kedalaman. Oleh karena itu, fungsi fitoplankton sebagai produsen primer dalam suatu perairan dapat dikatakan baik jika perairan tersebut memiliki tingkat kedalaman yang mampu ditembus oleh sinar matahari. Dari pernyataan tersebut, maka stasiun 1 Rawa Nebong kuning, memiliki kriteria yang dimaksud dibandingkan dengan stasiun pengamatan lainnya dengan memiliki tingkat kedalaman antara 2,5m - $4 \mathrm{~m}$.

Rendahnya nilai rata-rata kelimpahan fitoplankton pada stasiun 2 Rawa Poron diduga karena fitoplankton tidak mampu beradaptasi dengan baik pada kondisi lingkungan yang ada. Hal ini sesuai dengan pendapat Aprisanti et al (2013) dalam Indrayani (2014) yang menyatakan bahwa keberadaan Bacillariophyceae (diatom) seperti Nitzschia di stasiun 2 Rawa Banan merupakan indikator spesies pada perairan yang tercemar ringan sampai sedang. Nitzschia memiliki range toleransi pencemaran bahan organik yang luas dan dapat berperan sebagai indikator pada kondisi perairan yang tercemar sedang hingga berat.

Indrayani (2014) juga menyatakan bahwa, kelimpahan plankton (fitoplankton dan zooplankton) pada suatu perairan erat kaitannya dengan kondisi lingkungan pada perairan tersebut. Hal ini dapat dilihat dari nilai rata-rata kelimpahan fitoplankton yang berbeda pada setiap stasiun pengamatan, dimana nilai rata-rata kelimpahan fitoplankton pada stasiun 1 Rawa Nebong kuning sebesar 39 ind/L, stasiun 2 Rawa Poron sebesar 15,42 ind/L dan stasiun 3 Rawa Banan sebesar 23,08 ind/L.

Nilai rata-rata kelimpahan fitoplankton, berdasarkan Landner (1978) dalam Suryanto (2009), maka perairan Rawa Banjiran Desa Sedang Kecamatan Suak Tapeh Kabupaten Banyuasin Provinsi Sumatera Selatan termasuk dalam kategori tingkat kesuburan rendah dan digolongkan 
perairan oligotrofik, dimana nilai kelimpahan fitoplankton berkisar antara 0 $-2000 \mathrm{ind} / \mathrm{L}$.

\section{KESIMPULAN}

Kelimpahan rata-rata fitoplankton pada stasiun 1 Rawa Nebong kuning berkisar antara 39 ind/L, stasiun 2 Rawa Poron berkisar antara 4,5 - 21 ind/L, stasiun 3 Rawa Banan berkisar antara 6,75 - 42,75 ind/L. Nilai kelimpahan fitoplankton tersebut berdasarkan pengindeksan Lander (1978) dalam Suryanto (2009), mengindikasikan bahwa perairan Rawa Banjiran di Desa Sedang Kecamatan Suak Tapeh Kabupaten Banyuasin Provinsi Sumatera Selatan memiliki tingkat kesuburan yang rendah dan termasuk perairan oligotrofik.

\section{DAFTAR PUSTAKA}

Efrizal, T. 2006. Hubungan beberapa Parameter Kualitas Air dengan Kelimpahan Fitoplankton di Perairan Pulau Penyengat Kota Tanjung Pinang Provinsi Kepulauan Riau. Fakultas IImu Kelautan dan Perikanan Maritim. Universitas Raja Ali Haji. Tanjung Pinang.

Indrayani, N. Anggoro, S., Suryanto, A. 2014. Indeks Tropik-Saprobik Sebagai Indikator Kualitas Air di Bendungan Kembang Kempis Wedung Kabupaten Demak. Diponegoro Journal of Maquares. Vol.3 No.4 : 161 - 168 .

Iswanto, C.Y., Hutabarat, S., Purnamo, P.W. 2015. Analisis Kesuburan Perairan Berdasarkan Keanekaragaman Plankton, Nitrat, dan Fosfat di Sungai Jali dan Sungai Lereng Desa Keburuhan Purworejo. Diponegoro Journal of Maquares. Vol.4 No.3 : 84 - 90.

Kordi, M.G. 2008. Budidaya Perairan. Buku ke-1. Citra Aditya Bakti. Bandung. xiii + $444 \mathrm{hlm}$.

Maresi, S.R.P,. Priyanti, Yunita, E. 2015. Fitoplankton Sebagai Bioindikator Saprobitas Perairan di Situ Bulakan Kota Tangerang. Jurnal al-Kauniyah. Vol 8 No.2 : 113 - 122.

Mizuno, T. 1979. Illustration the Freshwater Plankton of Japan. Hoikusha Publishing. Japan.

Suryanto, A.M., Umi, H. 2009. Pendugaan Status Tropik Dengan Pendekatan Kelimpahan Fitoplankton dan Zooplankton di Waduk Sengguruh, Karangkates, Lahor, Wlingi Raya dan Wonorejo, Jawa Timur. Jurnal IImiah Perikanan dan Kelautan. Vol. 1 : 7 -13. 
E-ISSN: 2527-5186. P-ISSN:2615-5958

Jurnal Enggano Vol. 4, No. 1, April 2019: 72-79

Yusanti, IA., Widayatsih, T. 2017. Keanekaragaman Fitoplankton Di Rawa Banjiran Desa Sedang Kecamatan Suak Tapeh Kabupaten Banyuasin. Prosiding Seminar Nasional Lahan Suboptimal. Palembang. 412-419 hlm. 